\title{
Soil Microbial Community Structure Evolution along Halophyte Succession in Bohai Bay Wetland
}

\author{
Mingyang Cong, ${ }^{1}$ Di Cao, ${ }^{2}$ Jingkuan Sun, ${ }^{3}$ and Fuchen Shi ${ }^{1}$ \\ ${ }^{1}$ Department of Plant Biology \& Ecology, College of Life Sciences, Nankai University, Weijin Road 94, Tianjin 300071, China \\ ${ }^{2}$ College of Life Science and Technology, Heilongjiang Bayi Agricultural University, Daqing 163319, China \\ ${ }^{3}$ Research Center for Eco-Environmental Sciences of Yellow River Delta, Binzhou University, Binzhou 256600, China
}

Correspondence should be addressed to Fuchen Shi; fcshi@nankai.edu.cn

Received 27 June 2014; Revised 4 October 2014; Accepted 18 October 2014; Published 9 November 2014

Academic Editor: Huiwang Gao

Copyright (C) 2014 Mingyang Cong et al. This is an open access article distributed under the Creative Commons Attribution License, which permits unrestricted use, distribution, and reproduction in any medium, provided the original work is properly cited.

\begin{abstract}
It is urgent to recover Bohai Bay costal wetland ecosystem because of covering a large area of severe saline-alkali soil. To explore the relationship between halophyte herbaceous succession and microbial community structure, we chose four local communities which played an important role in improving soil microenvironment. We performed phospholipid fatty acid analysis, measured soil parameters, and evaluated shifts of microbial community structure. Results showed that microbial community structure changed significantly along succession and bacteria community was dominant. Total phospholipid fatty acid content increased in different successional stages but decreased with depth, with similar variations in bacterial and fungal biomass. Soil organic carbon and especially total nitrogen were positively correlated with microbial biomass. Colonization of pioneering salt-tolerant plants Suaeda glauca in saline-alkali bare land changed total soil microorganism content and composition. These results showed that belowground processes were strongly related with aboveground halophyte succession. Fungal/bacterial ratio, Gram-negative/Gram-positive bacteria ratio, total microbial biomass, and fungi and bacteria content could indicate the degree of succession stages in Bohai Bay wetland ecosystem. And also these findings demonstrated that microbial community biomass and composition evolved along with vegetation succession environmental variables.
\end{abstract}

\section{Introduction}

Vegetation, soil, and microbes depend on and restrict each other [1]. Microbes are sensitive to external environmental changes, and the most remarkable characteristic is the ability to change the community structure [2]. The role of soil microorganisms in the ecosystem is to decompose organic matter in the soil and promote formation of humus $[3,4]$, absorb, fix, and release nutrients, and improve and regulate nutrition in plants $[5,6]$. Previous studies examining relationship between vegetation succession and microbial communities were conducted in a forest ecosystem [7], karst ecosystem [8], or volcanic desert ecosystem [9]. However, studies on examining an extreme saline-alkali wetland ecosystem are rare. Beidagang wetland is one of the most important wetlands located in Bohai Bay, which is officially included in "list of important wetlands in China." Coastal wetlands are fragile and sensitive ecological areas with poor soil. On account of different climate and soil conditions from inland, the vegetation has unique characteristics. High salinity soil samples from four plots representing different successional stages were collected for this study. Main local halophyte in study site included Suaeda glauca and Phragmites australis. Suaeda glauca is a kind of leafy succulent plant that can accumulate salt ions. Such a strong alkali euhalophyte can decrease the salt content of topsoil during growing season. On the contrary, Phragmites australis is a kind of salt-excluding plant which can reduce its own salt concentration through physiological structure of cell membrane in roots [10].

A phospholipid fatty acid (PLFA) method was employed to examine the soil microbial community. PLFAs are important components of living microbe cell membrane and are synthesized by various microorganisms through different biochemical pathways. Thus, PLFAs can accurately express the biomass and composition of the soil microbial community [11]. 


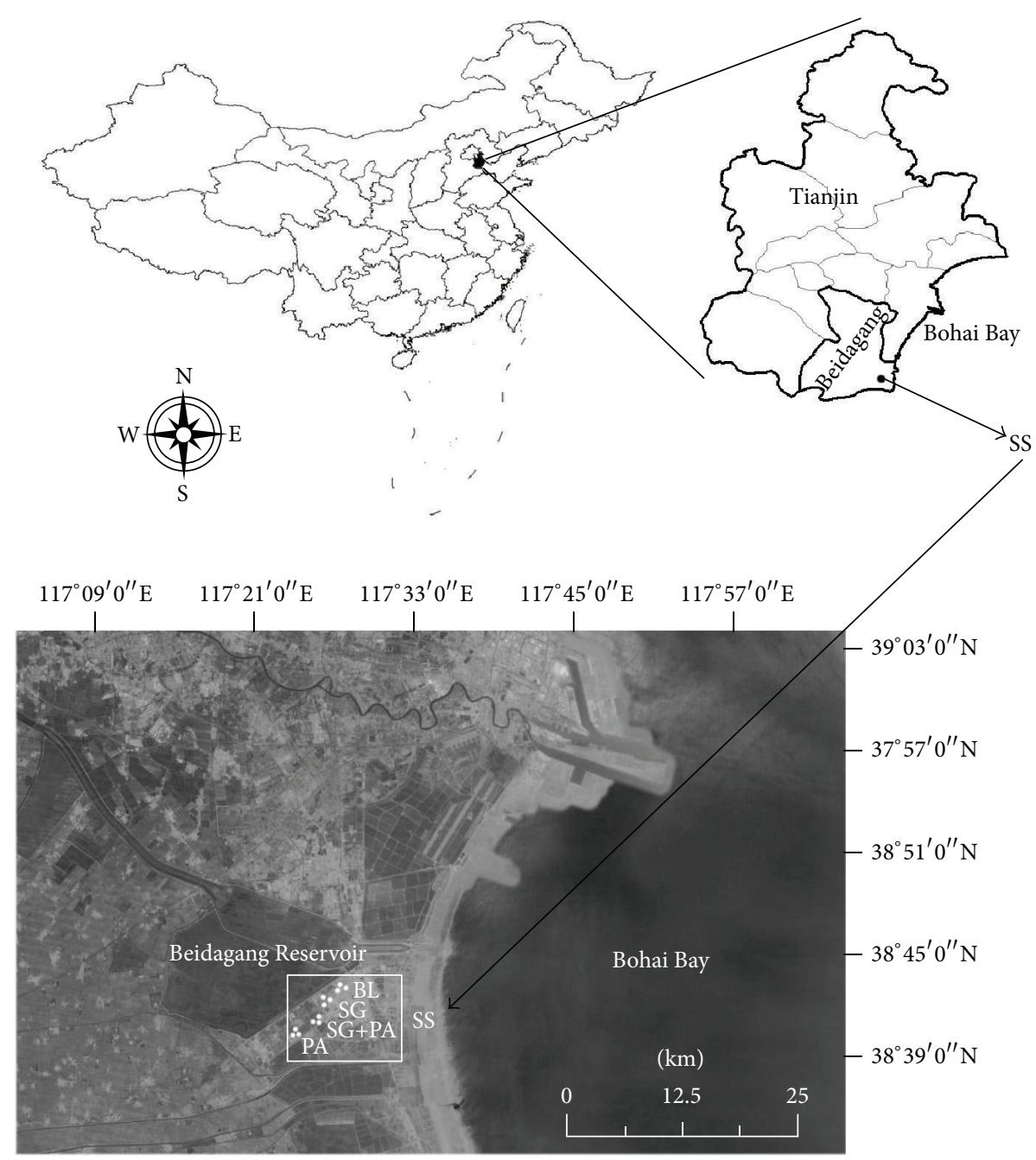

FIGURE 1: Locations of study and sample sites (SS) near the Bohai Bay. Details of the plots and abbreviation names of dominant species are listed in Table 1.

The aims of this study were to elucidate (1) the response of microorganism community structural composition to, along with environmental changes caused by, halophyte succession, and (2) main factors influencing soil microbial community structure along with succession. The results of this study may offer critical information for ecological restoration and soil quality improvement in severe saline-alkali wetlands.

\section{Materials and Methods}

2.1. Study Sites. It was located in the southeast of Tianjin near Bohai Bay, middle-east of China $\left(117^{\circ} 27^{\prime} \mathrm{E}, 38^{\circ} 43^{\prime} \mathrm{N}\right.$ ) (Figure 1 and Table 1). It was characterized by a warm semihumid continental monsoon climate. Annual mean temperature was approximately $12.2^{\circ} \mathrm{C}$, with the coldest (January) and hottest (July) mean temperatures of $3.5^{\circ} \mathrm{C}$ and $26.2^{\circ} \mathrm{C}$, respectively. Annual mean precipitation was $520-660 \mathrm{~mm}$, and $75 \%$ was summer rainfall (July-September). The study area was covered by extreme saline-alkali soil, together with larger amount of evaporation and smaller amount of precipitation. The soil in this area was barren. Landform was a coastal floodplain with sparse vegetation.

2.2. Soil Sampling. We investigated four community types with three repetitions in June 2013. Table 1 summarized the information of four successional stages, covering average height, coverage, biomass, and altitude of dominant species. The four typical communities examined were (I) saline-alkali bare land (BL), (II) Suaeda glauca community (SG), (III) Suaeda glauca + Phragmites australis community (SG + PA), and (IV) Phragmites australis community (PA). Soil samples were collected using multipoint mixed method with three vertical layers, S1 $(0-10 \mathrm{~cm}), \mathrm{S} 2(10-20 \mathrm{~cm})$, and S3 $(20-$ $30 \mathrm{~cm})$. We collected in two times on account of different analyses. One set was used to measure bulk density and moisture content by a cutting ring. Another set was divided into two parts: for PLFA analysis, kept at $-20^{\circ} \mathrm{C}$; for parameter analyses, dried in shade, homogenized, and sieved before preserved. 
TABLE 1: Dominant species in plots.

\begin{tabular}{|c|c|c|c|c|c|}
\hline Stage & Plant community & Average height $(\mathrm{cm})$ & Coverage $(\%)$ & Biomass $\left(\mathrm{g} \mathrm{m}^{-2}\right)$ & Altitude (m) \\
\hline I & Saline-alkali bare land & - & - & - & 10 \\
\hline II & Suaeda glauca & 16 & 74 & $1.8 \pm 0.4$ & 10.3 \\
\hline \multirow{2}{*}{ III } & \multirow{2}{*}{ Suaeda glauca + Phragmites australis } & 24 & 69 & $2.3 \pm 0.3$ & 10.6 \\
\hline & & 109 & 66 & $169 \pm 10$ & 10.6 \\
\hline IV & Phragmites australis & 136 & 83 & $192 \pm 7$ & 11 \\
\hline
\end{tabular}

2.3. Soil Physicochemical Analyses. Soil organic carbon (SOC) and total nitrogen (TN) were measured by combustion using a macroelement analyzer (vario MACRO CN, Elementar Analysensysteme GmbH, Germany). Bulk density and moisture content were determined with samples dried in oven at $105^{\circ} \mathrm{C}$ for $48 \mathrm{~h}$ until a constant weight. Soil $\mathrm{pH}$ was determined with air-dried soil (soil : water, 1:2.5) using a glass electrode Sartorius PB-10 pH meter (Sartorius, Germany). Salinity was determined by drying-weighing method. Filtrate (soil: water, 1:5) was placed in oven at $105^{\circ} \mathrm{C}$ to constant weight.

2.4. Phospholipid Fatty Acid Analysis (PLFA). PLFAs are found in living microbial cell membranes and can be used as markers of biomass and a fingerprint of the microorganism community structure $[2,12]$. PLFA affords a quick and reliable method for estimating microbial biomass and interpreting variations in community structures [13]. Ester-linked method was used for fatty acid methyl ester (FAME) profile analyses [14]. The specific procedure to extracting phospholipids was divided into six steps: (1) $15 \mathrm{~mL}$ of $0.2 \mathrm{M} \mathrm{KOH}$ in methanol was added to a $35 \mathrm{~mL}$ centrifuge tube containing $3 \mathrm{~g}$ of soil. (2) The mixture was incubated at $37^{\circ} \mathrm{C}$ for $1 \mathrm{~h}$, and during the process ester-linked fatty acids were released and methylated. Samples were vortexed every $10 \mathrm{~min}$. (3) $3 \mathrm{~mL}$ of $1.0 \mathrm{M}$ acetic acid and $10 \mathrm{~mL}$ of hexane were added to the contents in the tube. (4) FAMEs were partitioned into an organic phase by centrifugation at $4800 \mathrm{r}$ for $10 \mathrm{~min}$. (5) The hexane layer was transferred to a clean glass test tube and the hexane was evaporated under a stream of $\mathrm{N}_{2}$. (6) FAMEs were dissolved in $0.5 \mathrm{~mL}$ of $1: 1$ hexane : methyl tert-butyl ether and transferred to a GC vial for analysis. FAMEs extracted were detected using a gas chromatograph-mass spectrometer (7890A GC/5975C MSD; Agilent Technologies Co., USA) fitted with an HP-5MS quartz capillary chromatographic column $(0.25 \mathrm{~mm} \times 30 \mathrm{~m} \times 0.25 \mu \mathrm{m})$, with an injector temperature at $250^{\circ} \mathrm{C}$. Internal standard for quantification was C19:0 (Sigma-Aldrich Co., USA), and external standard for qualification was GLC NESTLE $37 \mathrm{mix}$ (Nu-Chek).

Bardgett et al. [15] previously demonstrated that the content and composition of PLFA in the soil reflected the biomass and structure of soil microbial communities. Results were analyzed by the MIDI system (Microbial ID, Inc.). Standard nomenclature was employed to describe FAMEs. We used the PLFA nomenclature pioneered by Frostegard et al. [12] and the total content of PLFA to indicate the total microbial biomass. Twelve fatty acids (15:0, i15:0, a15:0, i16:0, $16: 1 \omega 7,16: 1 \omega 9,17: 0, \mathrm{i} 17: 0$, a17:0, 18:1 $\omega 7, \mathrm{i} 19: 0$, and cy19:0) were chosen as indicators of bacterial PLFA [16]. Fungal PLFA

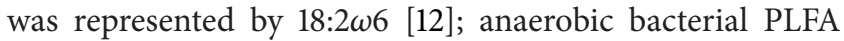
was represented by cy17:0 and cy19:0 [17]; aerobic bacterial

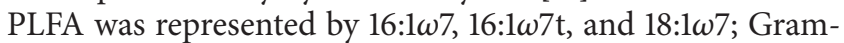
negative bacterial PLFA and monounsaturated fatty acids were represented by cy17:0 and cy19:0 [18]; Gram-positive bacterial PLFAs were represented by five fatty acids (i15:0, a15:0, i16:0, i17:0, and a17:0) [19].

2.5. Statistical Analyses. Statistical analyses were conducted with SPSS 17.0 software for Windows. One-way analysis of variance (ANOVA) was used to test for significant differences among the four successional stages and among the three soil layers in each stage. We subdivided the data into three sets: vegetation data (average height, coverage, and biomass), soil data (SOC, TN, C/N ratio, $\mathrm{pH}$, soil moisture content, bulk density, and salinity), and microbial community diversity. We used Duncan's multiple range tests and defined significance as $P<0.05$ in both the vertical and horizontal gradients. We used Spearman's rank correlations to examine the association between the microbial PLFA content and the physicochemical characteristics in soil $(P<0.01)$. Redundancy discriminate analysis (RDA), a linear canonical community ordination method, was used to explore the vital soil factors leading to changes in the microbial community structure with Canoco for Windows 4.5. The Monte Carlo permutation test (number of permutations, 999) was conducted with $P$ values to assess the significance of soil variables in accounting for the shifts in microbial community parameters.

\section{Results}

3.1. Soil Physicochemical Analyses. Percentage of SOC decreased vertically but increased along four stages (Table 2). The maximum value of SOC in S1 of stage IV was 1.8-3 times that of the other stages, and stage I had the lowest value. Variation in TN followed the same pattern as SOC. Although $\mathrm{C} / \mathrm{N}$ ratio declined with depth, it increased along succession. Soil pH ranged from 8.38 to 9.31 and increased with soil depth. Soil salinity values decreased markedly with deeper soil layers, especially in stage I, and also decreased along with succession stages. Moisture content reduced not only in vertical direction but also along succession. Value of bulk density was the lowest in S1 and decreased with each successional stage but fluctuated in S2 and S3.

3.2. PLFA Composition and Content. We detected 43 PLFAs, with the least in stage I (19), increasing in stages II and III (25 and 26, resp.) and reached the maximum in stage IV (39). 
TABLE 2: Soil parameters in successional stages.

\begin{tabular}{|c|c|c|c|c|c|c|c|c|}
\hline Stage & Layer & SOC (\%) & TN (\%) & $\mathrm{C} / \mathrm{N}$ ratio & $\mathrm{pH}$ & $\begin{array}{l}\text { Moisture content } \\
\left(\mathrm{g} \mathrm{g}^{-1}\right)\end{array}$ & $\begin{array}{l}\text { Bulk density } \\
\left(\mathrm{g} \mathrm{cm}^{-3}\right)\end{array}$ & Salinity (\%) \\
\hline \multirow{3}{*}{ I } & S1 & $1.33(0.06)^{\mathrm{Aa}}$ & $0.06(0.00)^{\mathrm{Aa}}$ & $22.10(0.66)^{\mathrm{Aa}}$ & $8.38(0.05)^{\mathrm{Ae}}$ & $18.78(0.43)^{\mathrm{Aa}}$ & $1.31(0.06)^{\mathrm{Aa}}$ & $5.22(0.18)^{\mathrm{Aa}}$ \\
\hline & S2 & $1.29(0.02)^{\mathrm{ABa}}$ & $0.03(0.01)^{\mathrm{Ba}}$ & $29.36(2.52)^{\mathrm{Ba}}$ & $8.59(0.03)^{\mathrm{Be}}$ & $20.69(0.35)^{\mathrm{Ba}}$ & $1.47(0.09)^{\mathrm{Aa}}$ & $1.85(0.45)^{\mathrm{Ba}}$ \\
\hline & S3 & $1.22(0.04)^{\mathrm{Ba}}$ & $0.03(0.00)^{\mathrm{Ba}}$ & $40.01(3.05)^{\mathrm{Ca}}$ & $8.71(0.02)^{\mathrm{Cf}}$ & $21.70(0.35)^{\mathrm{Ca}}$ & $1.47(0.06)^{\mathrm{Aa}}$ & $0.94(0.69)^{\mathrm{Ba}}$ \\
\hline \multirow{3}{*}{ II } & S1 & $1.70(0.13)^{\mathrm{Aab}}$ & $0.08(0.02)^{\mathrm{Aa}}$ & $20.05(1.62)^{\mathrm{Aa}}$ & $8.90(0.01)^{\mathrm{Aa}}$ & $16.47(0.59)^{\mathrm{Ab}}$ & $1.23(0.08)^{\mathrm{Aa}}$ & $0.71(0.16)^{\mathrm{Ac}}$ \\
\hline & S2 & $1.29(0.03)^{\mathrm{Ba}}$ & $0.04(0.00)^{\mathrm{Ba}}$ & $27.26(0.53)^{\mathrm{Bb}}$ & $8.97(0.03)^{\mathrm{Bb}}$ & $20.73(0.36)^{\mathrm{Ba}}$ & $1.40(0.05)^{\mathrm{Ba}}$ & $0.84(0.03)^{\mathrm{Bb}}$ \\
\hline & S3 & $1.23(0.01)^{\mathrm{Ba}}$ & $0.03(0.01)^{\mathrm{Bab}}$ & $34.54(0.51)^{\mathrm{Ca}}$ & $9.06(0.02)^{\mathrm{Cb}}$ & $21.13(0.23)^{\mathrm{Ba}}$ & $1.30(0.02)^{\mathrm{ABabc}}$ & $0.78(0.02)^{\mathrm{Ba}}$ \\
\hline \multirow{3}{*}{ III } & S1 & $2.29(0.39)^{\mathrm{Ab}}$ & $0.14(0.04)^{\mathrm{Aa}}$ & $16.08(1.25)^{\mathrm{Ab}}$ & $8.45(0.02)^{\mathrm{Ad}}$ & $15.50(0.58)^{\mathrm{Ab}}$ & $1.03(0.12)^{\mathrm{Ab}}$ & $0.67(0.24)^{\mathrm{Ac}}$ \\
\hline & S2 & $1.33(0.01)^{\mathrm{Ba}}$ & $0.04(0.00)^{\mathrm{Ba}}$ & $35.43(1.26)^{\mathrm{Bb}}$ & $8.74(0.02)^{\mathrm{Ba}}$ & $16.22(0.09)^{\mathrm{Ac}}$ & $1.41(0.08)^{\mathrm{Ba}}$ & $0.48(0.01)^{\mathrm{Abc}}$ \\
\hline & S3 & $1.24(0.01)^{\mathrm{Ba}}$ & $0.04(0.00)^{\mathrm{Bbc}}$ & $43.16(2.58)^{\mathrm{Cb}}$ & $8.77(0.01)^{\mathrm{Ca}}$ & $17.43(0.41)^{\mathrm{Bb}}$ & $1.38(0.10)^{\mathrm{Bab}}$ & $0.45(0.00)^{\mathrm{Aa}}$ \\
\hline \multirow{3}{*}{ IV } & S1 & $4.12(0.88)^{\mathrm{Ac}}$ & $0.33(0.08)^{\mathrm{Ab}}$ & $12.72(0.31)^{\mathrm{Ac}}$ & $8.46(0.01)^{\mathrm{Ad}}$ & $14.58(0.14)^{\mathrm{Aa}}$ & $0.88(0.08)^{\mathrm{Ac}}$ & $0.37(0.03)^{\mathrm{Ac}}$ \\
\hline & S2 & $1.46(0.02)^{\mathrm{Bb}}$ & $0.05(0.01)^{\mathrm{Bb}}$ & $27.61(3.31)^{\mathrm{Bb}}$ & $9.04(0.06)^{\mathrm{Bd}}$ & $15.93(0.04)^{\mathrm{Bb}}$ & $1.18(0.09)^{\mathrm{Bc}}$ & $0.29(0.01)^{\mathrm{Bc}}$ \\
\hline & S3 & $1.45(0.09)^{\mathrm{Bb}}$ & $0.04(0.01)^{\mathrm{Bc}}$ & $31.89(1.88)^{\mathrm{Cb}}$ & $9.31(0.01)^{\mathrm{Ce}}$ & $17.08(0.42)^{\mathrm{Cb}}$ & $1.17(0.15)^{\mathrm{Bc}}$ & $0.22(0.01)^{\mathrm{Ca}}$ \\
\hline
\end{tabular}

Numbers in parentheses are standard errors. Capital and small letters represent significant differences among soil depths within the same successional stage and among successional stages within the same soil depth, respectively $(P<0.05)$.

TABLE 3: Spearman's rank correlation analysis between soil microbial PLFA content and soil parameters.

\begin{tabular}{|c|c|c|c|c|c|c|c|}
\hline $\begin{array}{l}\text { Microbial } \\
\text { community }\end{array}$ & SOC & $\mathrm{TN}$ & $\mathrm{C} / \mathrm{N}$ ratio & Moisture content & Bulk density & Soil pH & Salinity \\
\hline Total PLFA & $0.724^{* *}$ & $0.766^{* *}$ & $-0.731^{* *}$ & $-0.799^{* *}$ & $-0.674^{* *}$ & $-0.461^{* *}$ & ns \\
\hline Bacterial PLFA & $0.753^{* *}$ & $0.760^{* *}$ & $-0.737^{* *}$ & $-0.844^{* *}$ & $-0.777^{* *}$ & $-0.481^{* *}$ & $-0.353^{*}$ \\
\hline Fungal PLFA & $0.720^{* *}$ & $0.625^{* *}$ & $-0.587^{* *}$ & $-0.821^{* *}$ & $-0.716^{* *}$ & ns & $-0.389^{* *}$ \\
\hline $\begin{array}{l}\text { Gram-positive } \\
\text { bacterial PLFA }\end{array}$ & $0.612^{* *}$ & $0.733^{* *}$ & $-0.735^{* *}$ & $-0.661^{* *}$ & $-0.593^{* *}$ & $-0.356^{*}$ & ns \\
\hline $\begin{array}{l}\text { Gram-negative } \\
\text { bacterial PLFA }\end{array}$ & $0.809^{* *}$ & $0.824^{* *}$ & $-0.803^{* *}$ & $-0.813^{* *}$ & $-0.781^{* *}$ & $-0.509^{* *}$ & ns \\
\hline
\end{tabular}

As shown in Figure $2(\mathrm{a})(P<0.05)$ total PLFA increased significantly from stages I to IV, while vertically values in S1 were significantly higher than S2 and S3 $(P<0.05)$. Pattern for bacterial (Figure 2(b)) and fungal PLFA (Figure 2(c)) was similar to total PLFA. By contrast, ratio of fungal PLFA to bacterial PLFA (F/B ratio) showed the opposite pattern in S2 and S3, with the value increasing as layers are deepening (Figure 2(d)).

3.3. Correlation Analysis of PLFA Content and Soil Parameters. The results showed that all types of microbial communities were positively correlated with SOC and TN but negatively correlated with $\mathrm{C} / \mathrm{N}$ ratio, soil moisture content, and bulk density (Table 3). Although fungi showed no significant correlations with $\mathrm{pH}$ value, PLFA content of all other microbes displayed negative correlations with $\mathrm{pH}$ value. Salinity showed negative correlations only with bacteria and fungi communities but showed no significant correlations with other kinds of microbial PLFA content.

3.4. Microbial Community Ratio Alterations. Along with vertical soil layers deepening, the proportion of fungal (Figure 3(a)) and Gram-negative bacterial PLFA (Figure 3(b)) decreased, whereas bacterial and Gram-positive bacterial
PLFA increased. In addition, there was a large variation between S1 and S2 (Figures 3(a) and 3(b)) but a small variation between S2 and S3. In successional gradient, the proportion of fungal (Figure 3(a)) and Gram-negative bacterial PLFA (Figure 3(b)) in all layers increased with each stage, whereas bacterial and Gram-positive bacterial PLFA decreased in all layers.

3.5. RDA Analyses. RDA revealed the relationship between two ratios (F/B and Gram-negative bacteria to Gram-positive bacteria) and seven (SOC, $\mathrm{TN}, \mathrm{C} / \mathrm{N}$ ratio, $\mathrm{pH}$, moisture content, bulk density, and salinity) key environmental factors. From Figure 4, we found that both SOC and TN markedly affected F/B and Gram-negative/Gram-positive ratios $(P<$ 0.001 ), while moisture content, $\mathrm{pH}$, and $\mathrm{C} / \mathrm{N}$ ratio were negatively correlated with the two ratios, and the effect for $\mathrm{pH}$ was less than moisture content and $\mathrm{C} / \mathrm{N}$ ratio. Besides, salinity and bulk density showed no significant effects on and were not main environmental factors to the two ratios.

\section{Discussion}

Microbial biomass reflects the size of populations involved in regulating energy and nutrient cycle of soil $[20,21]$. 


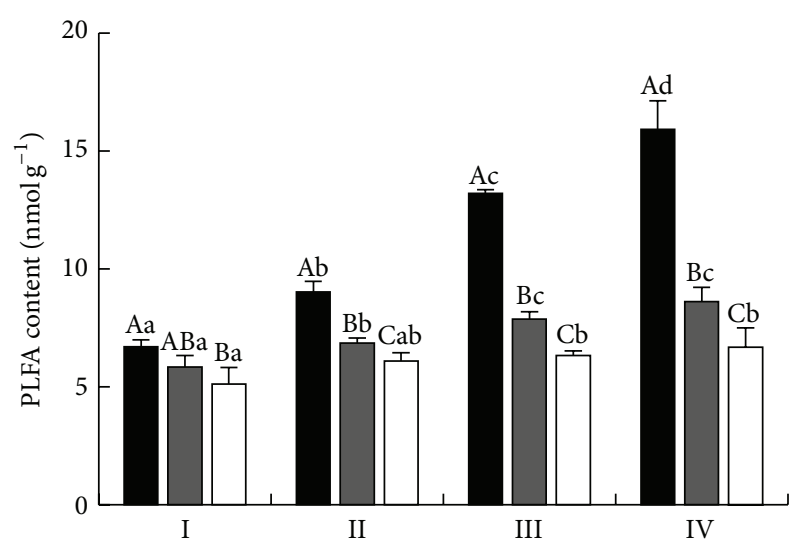

(a) Total PLFA

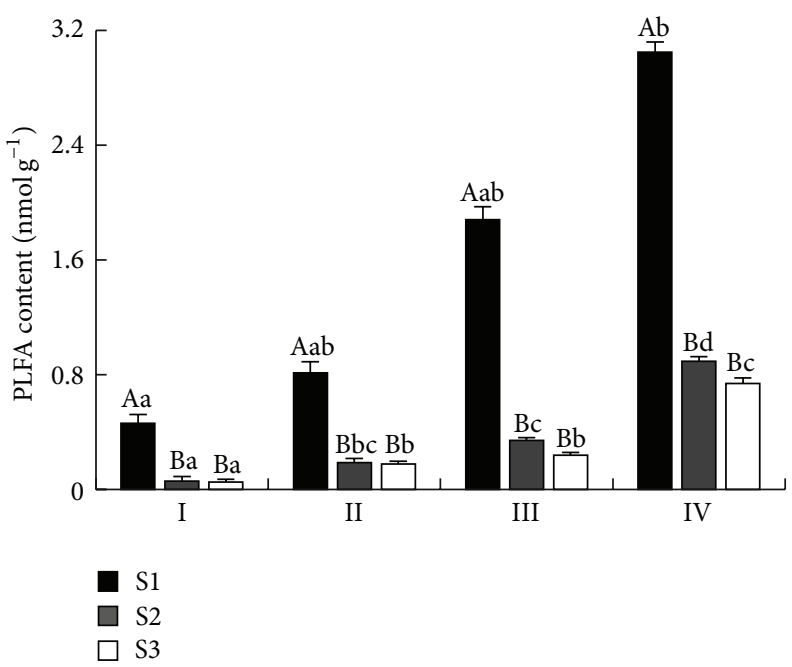

(c) Fungal PLFA

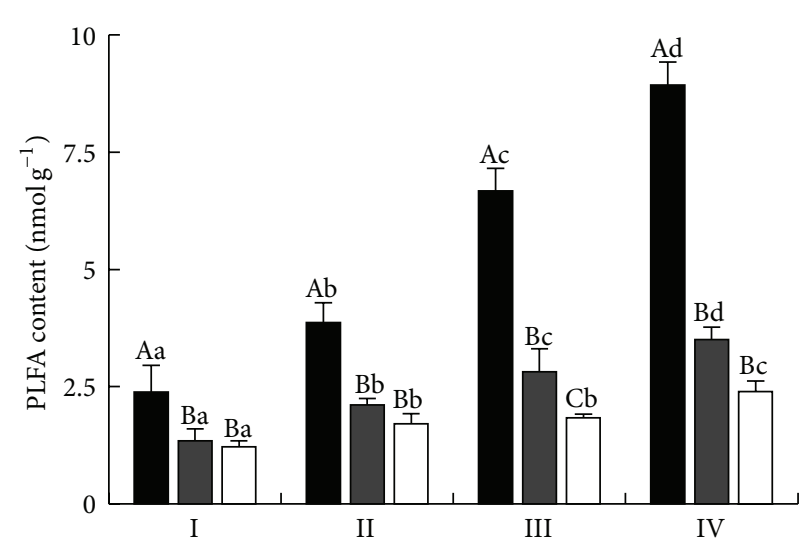

(b) Bacterial PLFA

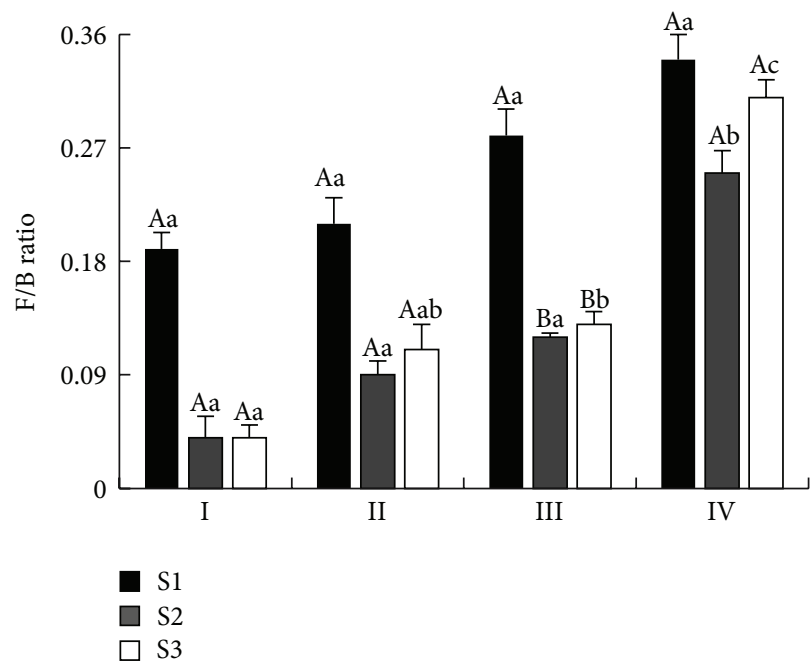

(d) $\mathrm{F} / \mathrm{B}$ ratio

Figure 2: Total PLFA (a), bacterial PLFA (b), fungal PLFA (c), and F/B ratio (d) in three layers (S1, S2, and S3) from four successional stages: (I) saline-alkali bare land, (II) Suaeda glauca, (III) Suaeda glauca + Phragmites australis, and (IV) Phragmites australis. Capital and small letters represent significant differences among soil depths within the same successional stage and among successional stages within the same soil depth, respectively $(P<0.05)$.

Results above suggested that the average height, coverage, and biomass of dominant species nearly increased along with successional stages and also for altitude (Table 1). In addition, soil parameters (Table 2) affected microbial biomass and structures (Figure 2). Spearman's correlation analysis (Table 3) showed that all microbial biomass was positively correlated with SOC and TN $(P<0.01)$, which suggested that SOC and TN levels can be represented by total PLFA, bacteria, or fungi content. Some researchers [22-25] have also reached the same conclusion in other ecosystems. All microbe biomass was negatively correlated with $\mathrm{C} / \mathrm{N}$ ratio, soil moisture, and bulk density, indicating that appropriate permeability and lower soil moisture content were beneficial to microbes [26]. Cook and Papendick [27] reported that bacteria were active at high water potential levels but fungi at low levels. However, we found the same results to bacteria (Figure 2(b)) and the opposite result to fungi (Figure 2(c)), which may be due to microtopography (Table 1). It is generally recognized that fungi are more tolerant to drought; then the reason why the highest value of fungi PLFA content appeared in successional stage IV is that the plot was located at the highest altitude. The highest topography gave rise to the lowest water potential and the most nutritious soil rich in SOC and TN. The $\mathrm{pH}$ was related to all microbial biomass, except for fungi in our study. However, Bååth and Anderson [28] reported that microbial biomass, especially fungi, was negatively related with $\mathrm{pH}$. Aciego Pietri and Brookes [29] and Wu et al. [30] reported that soil with higher $\mathrm{pH}$ was richer in Gram-negative than Gram-positive bacteria. In our study, total microbial, bacterial, and fungal biomass increased along with succession accompanying salinity decline. It indicated that higher salinity inhibited growth of microbes, which may be responsible for sparse vegetation in degraded wetlands [31]. Thus, soil structure, air and water permeability, and nutrient influenced microbial communities during vegetation succession [32] and then these factors affected vegetation 


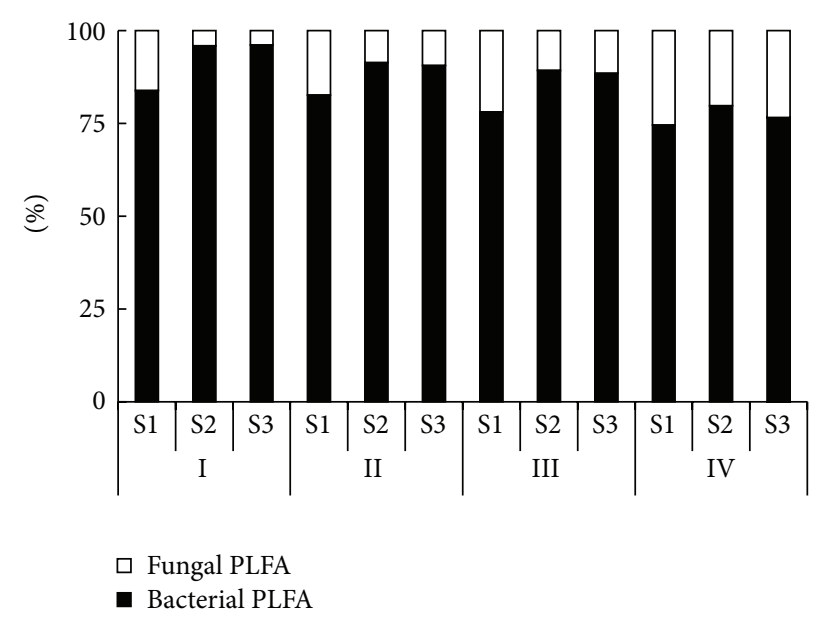

(a)

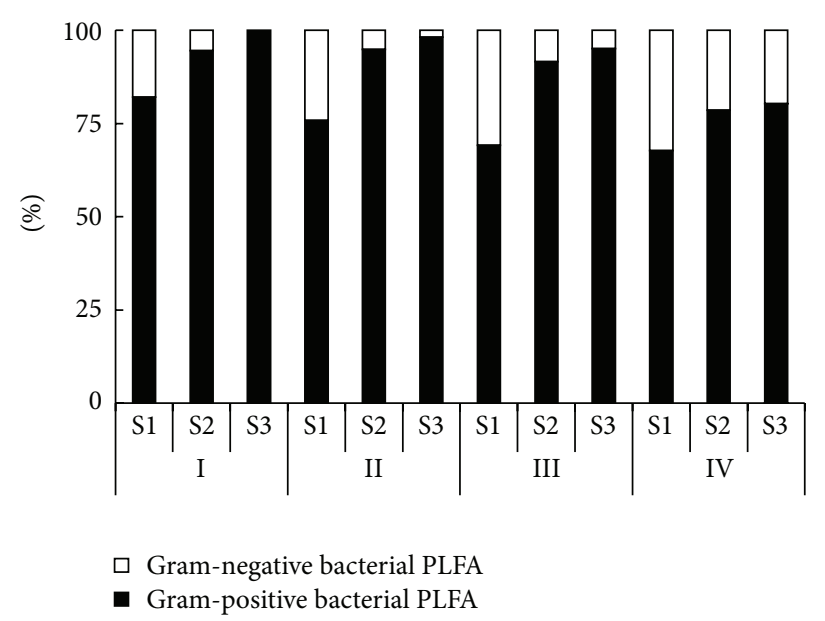

(b)

FIGURE 3: Ratios of fungal to bacterial PLFA (a) and Gram-negative bacterial to Gram-positive bacterial PLFA (b) in three layers (S1, S2, and S3) from four successional stages: (I) saline-alkali bare land, (II) Suaeda glauca, (III) Suaeda glauca + Phragmites australis, and (IV) Phragmites australis.

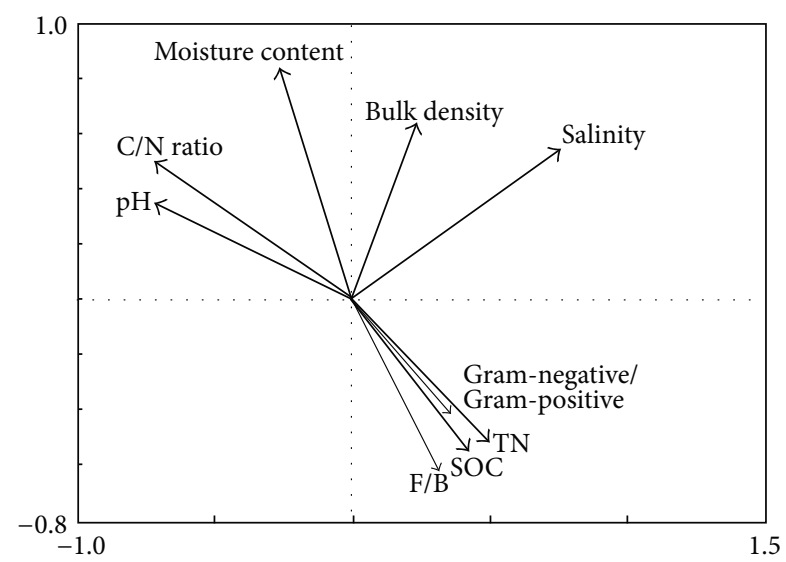

FIGURE 4: Redundancy discriminate analysis representing seven parameters (soil organic carbon, total nitrogen, $\mathrm{C} / \mathrm{N}$ ratio, soil moisture, bulk density, $\mathrm{pH}$, and salinity) and ratios for two microbial groups: fungal PLFA/bacterial PLFA and Gram-negative/Grampositive bacteria.

development and succession. No consensus has been reached regarding the impact of vegetation on microbes in coastal ecosystems. Su et al. [33] reported that presence or absence of Typha angustifolia did not influence biomass of bacteria and fungi in sediments of wetlands.

Microbial biomass showed obviously vertical distribution and decreased with depth increase (Figure 2). Microbes lived mainly in topsoil, which demonstrated that rhizosphere was active interface for mass exchange between soil and plants. Total microbial biomass (Figure 2(a)) increased along succession, suggesting that succession promoted quantity of microbial accumulation. Similar results were observed for bacteria (Figure 2(b)) and fungi (Figure 2(c)). F/B ratio (Figure 2(d)) peaked in S1 of stage IV suggesting that the higher the $\mathrm{F} / \mathrm{B}$ ratio, the greater the stability of wetland ecosystem, and it meant that Phragmites australis had reached the climatic successional stage. Therefore, F/B ratio reflected degree of succession. de Vries et al. [34] reached the same conclusion. Bacteria were dominant in extreme saline-alkali wetland because it showed higher biomass than fungi in each successional stage, which is consistent with the report by $\mathrm{Li}$ et al. [35]. In general, the greater the amount of fungi, the better the relative soil condition. Fungal biomass rose significantly in stages III and IV as a result of roots development by Phragmites australis, which reduced soil bulk density, improved permeability of topsoil, and benefited the survival of fungi.

The proportions of fungi and Gram-negative bacteria increased when high carbon material was introduced into the soil, while the proportion of Gram-positive bacteria was reduced (Figure 3 ). It could hold true in study by Griffiths et al. [36]. Gram-negative bacteria were dominant microbial group. The proportion of Gram-negative bacteria increased along with vegetation succession. By contrast, decrease of Gram-positive bacteria may be due to a unique mechanism of adapting acidic environments [37], or pH may have increased the effectiveness of sugars and amino acids to promote Gramnegative bacterial growth. RDA also indicated that (Figure 3) the major factors especially SOC and TN impacted on ratios of microbes $(P<0.001)$.

\section{Conclusions}

Taken together, our study indicated that the evolution of soil microbial communities underground in extreme saline-alkali wetland was closely associated with the succession of vegetation aboveground. Microbe biomass and structure changed significantly not only along with vegetation succession, but also in vertical soil layers. The colonization of pioneer Suaeda glauca improved the soil condition, including the increase of SOM and TN as well as the decrease of soil density and 
salinity. It was not due to a single factor but the result of multiple cooperating factors. SOC and especially TN levels were the main factors affecting microbial communities. However, soil salinity had no effect on fungi/bacteria and Gramnegative/Gram-positive ratios. Microorganism responded to microenvironment changes through rhizosphere. Bacteria were dominant, and fungi played an important role in soil nutrient cycling with succession.

\section{Conflict of Interests}

The authors declare that there is no conflict of interests regarding the publication of this paper.

\section{Acknowledgments}

This work was supported by the National Science Foundation for Fostering Talents in Basic Research of National Natural Science Foundation of China under Grant no. J1103503; Tianjin Wild Plant Resources Survey of Wildlife Conservation and Management Station under Grant 2011FY110300; and Foundation of the Research Center for Eco-Environmental Sciences of the Yellow River Delta in Shandong Province under Grant no. 2013KFJJ03.

\section{References}

[1] D. A. Wardle, R. D. Bardgett, J. N. Klironomos, H. Setälä, W. H. van der Putten, and D. H. Wall, "Ecological linkages between aboveground and belowground biota," Science, vol. 304, no. 5677, pp. 1629-1633, 2004.

[2] D. C. White, W. M. Davis, J. S. Nickels, J. D. King, and R. J. Bobbie, "Determination of the sedimentary microbial biomass by extractible lipid phosphate," Oecologia, vol. 40, no. 1, pp. 5162, 1979.

[3] C. R. Vossbrinck, D. C. Coleman, and T. A. Woolley, "Abiotic and biotic factors in litter decomposition in a semiarid grassland," Ecology, vol. 60, no. 2, pp. 265-271, 1979.

[4] J. Cortez and M. Bouché, "Decomposition of mediterranean leaf litters by Nicodrilus meridionalis (Lumbricidae) in laboratory and field experiments," Soil Biology and Biochemistry, vol. 33, no. 15, pp. 2023-2035, 2001.

[5] J. S. Singh, A. S. Raghubanshi, R. S. Singh, and S. C. Srivastava, "Microbial biomass acts as a source of plant nutrients in dry tropical forest and savanna," Nature, vol. 338, no. 6215, pp. 499$500,1989$.

[6] S. Roy and J. S. Singh, "Consequences of habitat heterogeneity for availability of nutrients in a dry tropical forest," Journal of Ecology, vol. 82, no. 3, pp. 503-509, 1994.

[7] T. Pennanen, R. Strömmer, A. Markkola, and H. Fritze, "Microbial and plant community structure across a primary succession gradient," Scandinavian Journal of Forest Research, vol. 16, no. 1, pp. 37-43, 2001.

[8] H. Zhu, X. He, K. Wang, Y. Su, and J. Wu, "Interactions of vegetation succession, soil bio-chemical properties and microbial communities in a Karst ecosystem," European Journal of Soil Biology, vol. 51, pp. 1-7, 2012.

[9] S. Yoshitake, M. Fujiyoshi, K. Watanabe, T. Masuzawa, T. Nakatsubo, and H. Koizumi, "Successional changes in the soil microbial community along a vegetation development sequence in a subalpine volcanic desert on Mount Fuji, Japan," Plant and Soil, vol. 364, no. 1-2, pp. 261-272, 2013.

[10] D. Cao, F. C. Shi, T. Koike, Z. H. Lu, and J. K. Sun, "Halophyte plant communities affecting enzyme activity and microbes in saline soils of the Yellow River Delta in China," CLEAN-Soil, Air, Water, vol. 42, no. 10, pp. 1433-1440, 2014.

[11] L. Zelles, "Fatty acid patterns of phospholipids and lipopolysaccharides in the characterisation of microbial communities in soil: a review," Biology and Fertility of Soils, vol. 29, no. 2, pp. 111-129, 1999.

[12] A. Frostegard, A. Tunlid, and E. Baath, "Phospholipid fatty acid composition, biomass, and activity of microbial communities from two soil types experimentally exposed to different heavy metals," Applied and Environmental Microbiology, vol. 59, no. 11, pp. 3605-3617, 1993.

[13] A. M. Ibekwe and A. C. Kennedy, "Phospholipid fatty acid profiles and carbon utilization patterns for analysis of microbial community structure under field and greenhouse conditions," FEMS Microbiology Ecology, vol. 26, no. 2, pp. 151-163, 1998.

[14] M. E. Schutter and R. P. Dick, "Comparison of fatty acid methyl ester (FAME) methods for characterizing microbial communities," Soil Science Society of America Journal, vol. 64, no. 5, pp. 1659-1668, 2000.

[15] R. D. Bardgett, P. J. Hobbs, and Å. Frostegård, "Changes in soil fungal: bacterial biomass ratios following reductions in the intensity of management of an upland grassland," Biology and Fertility of Soils, vol. 22, no. 3, pp. 261-264, 1996.

[16] Å. Frostegård and E. Bååth, “The use of phospholipid fatty acid analysis to estimate bacterial and fungal biomass in soil," Biology and Fertility of Soils, vol. 22, no. 1-2, pp. 59-65, 1996.

[17] J. R. Vestal and D. C. White, "Lipid analysis in microbial ecology: quantitative approaches to the study of microbial communities," Bioscience, vol. 39, no. 8, pp. 535-541, 1989.

[18] L. Zelles, "Phospholipid fatty acid profiles in selected members of soil microbial communities," Chemosphere, vol. 35, no. 1-2, pp. 275-294, 1997.

[19] A. Frostegård, Å. Tunlid, and E. Bååth, "Microbial biomass measured as total lipid phosphate in soils of different organic content," Journal of Microbiological Methods, vol. 14, no. 3, pp. 151-163, 1991.

[20] K. Arunachalam, A. Arunachalam, and N. P. Melkania, "Influence of soil properties on microbial populations, activity and biomass in humid subtropical mountainous ecosystems of India," Biology and Fertility of Soils, vol. 30, no. 3, pp. 217-223, 1999.

[21] J. P. Taylor, B. Wilson, M. S. Mills, and R. G. Burns, “Comparison of microbial numbers and enzymatic activities in surface soils and subsoils using various techniques," Soil Biology and Biochemistry, vol. 34, no. 3, pp. 387-401, 2002.

[22] D. S. Jenkinson and D. S. Powlson, "The effects of biocidal treatments on metabolism in soil-V: a method for measuring soil biomass," Soil Biology and Biochemistry, vol. 8, no. 3, pp. 209-213, 1976.

[23] H. Insam and K. H. Domsch, "Relationship between soil organic carbon and microbial biomass on chronosequences of reclamation sites," Microbial Ecology, vol. 15, no. 2, pp. 177-188, 1988.

[24] D. M. Mao, Y. W. Min, L. L. Yu, R. Martens, and H. Insam, "Effect of afforestation on microbial biomass and activity in soils of tropical China," Soil Biology \& Biochemistry, vol. 24, no. 9, pp. 865-872, 1992. 
[25] H. Y. Yao, Z. L. He, and C. Y. Huang, "Phospholipid fatty acid profiles of chinese red soils with varying fertility levels and land use histories," Pedosphere, vol. 11, no. 2, pp. 97-103, 2001.

[26] M. A. Williams and C. W. Rice, "Seven years of enhanced water availability influences the physiological, structural, and functional attributes of a soil microbial community," Applied Soil Ecology, vol. 35, no. 3, pp. 535-545, 2007.

[27] R. J. Cook and R. I. Papendick, "Soil water potential as a factor in the ecology of Fusarium roseum f. sp. cerealis 'Culmorum," Plant and Soil, vol. 32, no. 1, pp. 131-145, 1970.

[28] E. Bååth and T. H. Anderson, "Comparison of soil fungal/bacterial ratios in a $\mathrm{pH}$ gradient using physiological and PLFA-based techniques," Soil Biology and Biochemistry, vol. 35, no. 7, pp. 955-963, 2003.

[29] J. C. Aciego Pietri and P. C. Brookes, "Substrate inputs and pH as factors controlling microbial biomass, activity and community structure in an arable soil," Soil Biology and Biochemistry, vol. 41, no. 7, pp. 1396-1405, 2009.

[30] Y. Wu, B. Ma, L. Zhou et al., "Changes in the soil microbial community structure with latitude in eastern China, based on phospholipid fatty acid analysis," Applied Soil Ecology, vol. 43, no. 2-3, pp. 234-240, 2009.

[31] S. Tripathi, S. Kumari, A. Chakraborty, A. Gupta, K. Chakrabarti, and B. K. Bandyapadhyay, "Microbial biomass and its activities in salt-affected coastal soils," Biology and Fertility of Soils, vol. 42, no. 3, pp. 273-277, 2006.

[32] N. Fierer, J. P. Schimel, and P. A. Holden, "Variations in microbial community composition through two soil depth profiles," Soil Biology \& Biochemistry, vol. 35, no. 1, pp. 167-176, 2003.

[33] R. Su, R. N. Lohner, K. A. Kuehn, R. Sinsabaugh, and R. K. Neely, "Microbial dynamics associated with decomposing Typha angustifolia litter in two contrasting Lake Erie coastal wetlands," Aquatic Microbial Ecology, vol. 46, no. 3, pp. 295-307, 2007.

[34] F. T. de Vries, E. Hoffland, N. van Eekeren, L. Brussaard, and J. Bloem, "Fungal/bacterial ratios in grasslands with contrasting nitrogen management," Soil Biology \& Biochemistry, vol. 38, no. 8, pp. 2092-2103, 2006.

[35] J.-J. Li, Y.-M. Zheng, J.-X. Yan, H.-J. Li, and J.-Z. He, "Succession of plant and soil microbial communities with restoration of abandoned land in the Loess Plateau, China," Journal of Soils and Sediments, vol. 13, no. 4, pp. 760-769, 2013.

[36] B. S. Griffiths, K. Ritz, N. Ebblewhite, and G. Dobson, "Soil microbial community structure: effects of substrate loading rates," Soil Biology \& Biochemistry, vol. 31, no. 1, pp. 145-153, 1999.

[37] P. D. Cotter and C. Hill, "Surviving the acid test: responses of gram-positive bacteria to low $\mathrm{pH}$," Microbiology and Molecular Biology Reviews, vol. 67, no. 3, pp. 429-453, 2003. 

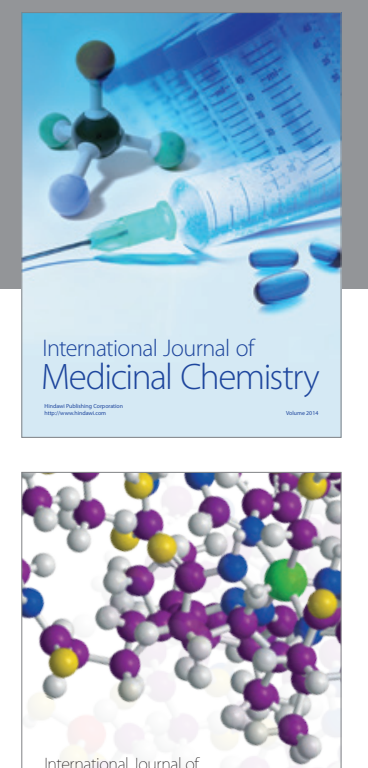

\section{Carbohydrate} Chemistry

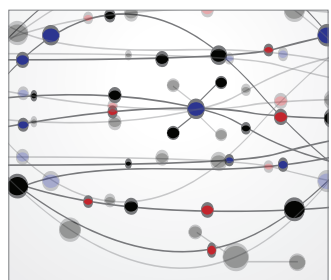

The Scientific World Journal
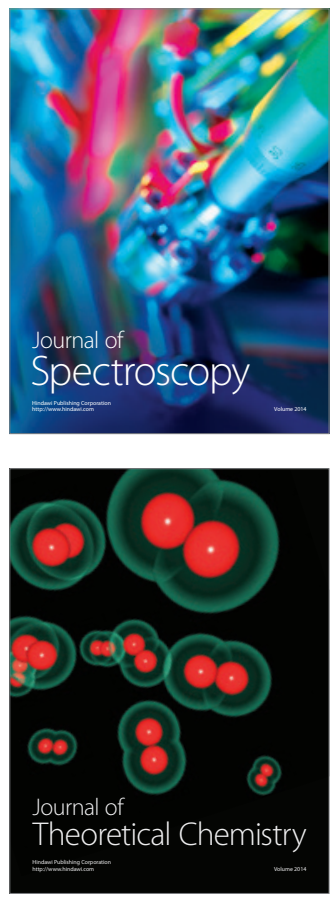
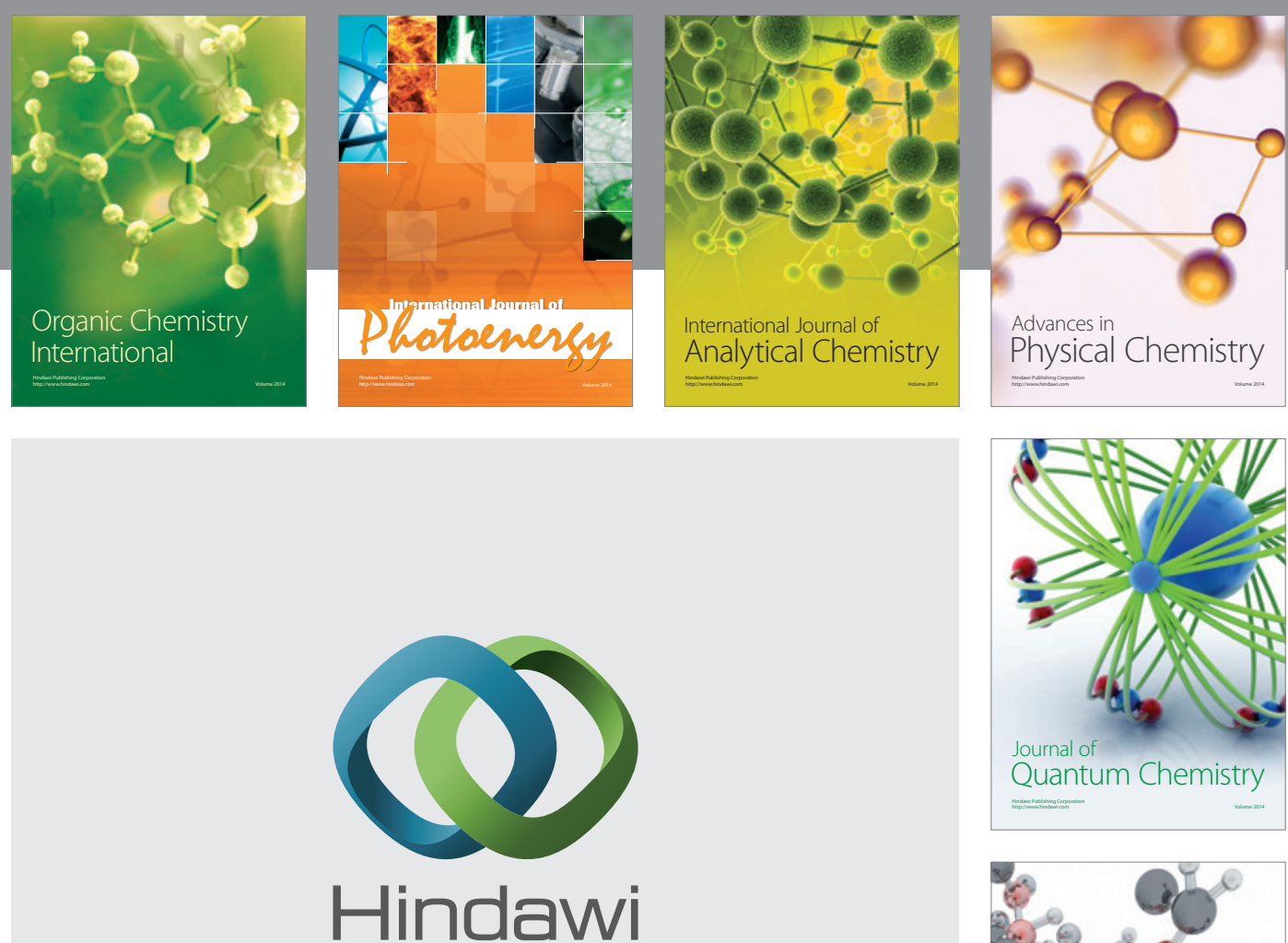

Submit your manuscripts at

http://www.hindawi.com

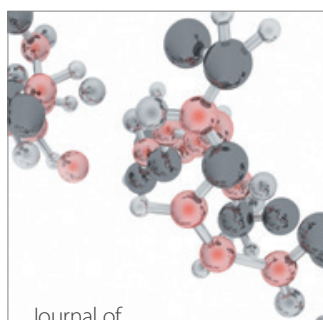

Analytical Methods

in Chemistry

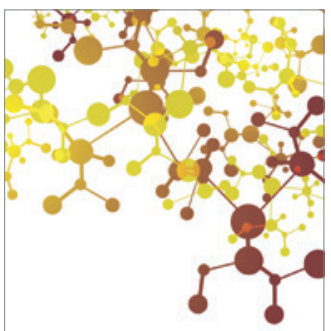

Journal of

Applied Chemistry

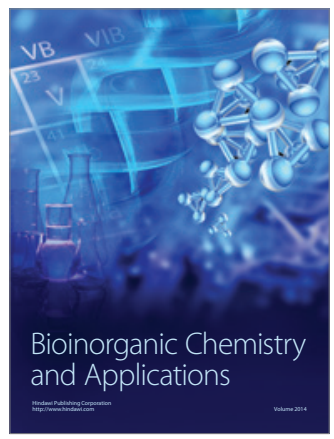

Inorganic Chemistry
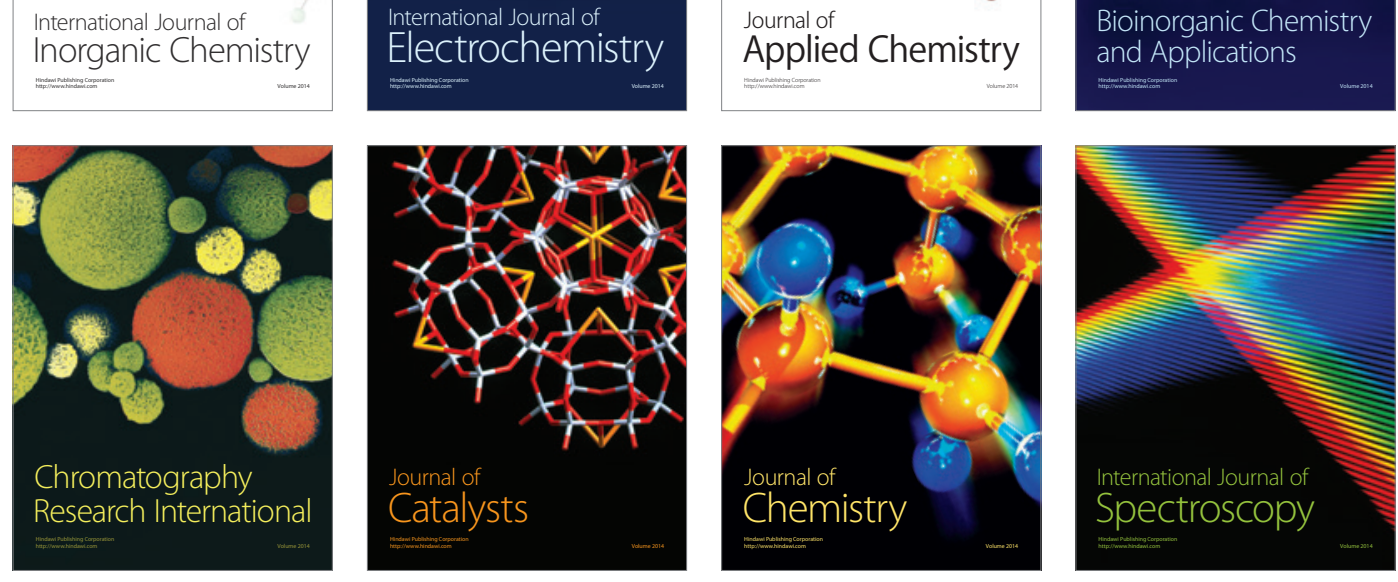